\title{
Karar İncelemesi: Ticari Dava Niteliğindeki İtirazın İptali Davasının Dava Şartı Arabuluculuğa Tabi Olup Olmadığına İlişkin Uyuşmazlığın Giderilmesine Yönelik Yargıtay 23. Hukuk Dairesi Kararının Değerlendirilmesi
}

\author{
Verdict Analysis: Evaluation of the 23rd Civil Department of the \\ Supreme Court of Appeals Decision for the Resolution of Disputes \\ Wheather the Action for Annulment of the Objection for Commercial \\ Disputes is Subject to Mediation as a Cause of Action
}

Elif Irmak Büyük* (iD

\section{öz}

Dava açılmadan önce zorunlu olarak arabulucuya başvurulması öngörülen 6102 Sayılı Türk Ticaret Kanunu $^{* *}$ m. 5/A kapsamındaki talepleri konu alan itirazın iptali davasının dava şartı (zorunlu) arabuluculuğa tabi olup olmadığı bu zamana kadar tartışmalı bir konu olmuştur. Nitekim farklı bölge adliye mahkemeleri hukuk daireleri bu konuda görüş ayrılığına düşmüş, benzer olaylarda ayrı kararlar verilmeye başlanmıștır. Başvuru üzerine Yargıtay 23. Hukuk Dairesi, TTK m. 5/A kapsamında olan taleplerin konu edildiği icra takiplerindeki itirazın iptali davasının dava şartı arabuluculuğa tabi olduğu yönde karar vererek daireler arasındaki uyuşmazlığı gidermiştir. Çalışmamızda ilgili mahkeme kararlarına yer verilip konuyla ilgili hukuki sorunlar tespit edilerek Yargitay 23. Hukuk Dairesi'nin vermiş olduğu kararın değerlendirilmesi yapılacaktır.

Anahtar Kelimeler: İtirazın İptali Davası, Dava Şartı Arabuluculuk, Bölge Adliye Mahkemeleri Hukuk Dairelerinin Görüş Ayrılıklarının Giderilmesi, İcra Tazminatı

\section{ABSTRACT}

It has been a controversial issue whether the action for annulment of the objection regarding the claims under the Turkish Commercial Code No. 6012 Art. 5/A, which is required to apply to a mediator before the lawsuit is filed, is subject to (mandatory) mediation as a cause of action. As a matter of fact, different civil chambers of regional courts of appeals fell into disagreement on this issue and separate decisions began to be made in similar cases. Upon the application, the 23rd Law Department of the Supreme Court of Appeals decided that the action for annulment of the objection filed for claims under the Turkish Commercial Code No. 6012 Art. 5/A is also subject to (mandatory) mediation as a cause of action and thereby the dispute between the civil chambers has been resolved. In our study, the decision of the 23rd Legal Department of the Supreme Court will be evaluated by including the relevant court decisions and determining the legal problems related to the issue.

Keywords: The Action for Annulment of the Objection, Mediation as A Cause of Action, Resolving of Different Decisions of the Civil Chambers of Regional Courts of Appeals, Execution Compensation

\footnotetext{
* Dr., İstanbul Medeniyet Üniversitesi Hukuk Fakültesi, Medeni Usul ve İcra İflas Hukuku Anabilim Dalı

** RG 14.02.2011, S. 27846. Çalışmada bundan sonra kısaca "TTK” olarak kullanılacaktır.

Sorumlu Yazar/Correspondence Author: Elif Irmak Büyük
}

E-posta/E-mail: elifirmak.kilic@medeniyet.edu.tr

Geliş Tarihi/Received: $\quad$ 24.04.2021

Kabul Tarihi/Accepted:

02.06 .2021 


\section{YARGI KARARLARINA KONU EDILEN UYUŞMAZLIĞIN ÖZETI}

Yargıtay 23. Hukuk Dairesi'nin kararına konu olan uyuşmazlık, ticari dava niteliğindeki itirazın iptali davasının TTK m. 5/A uyarınca dava şartı arabuluculuğa tabi olan uyuşmazlıklardan sayılıp sayılmayacağına ilişkin çeşitli bölge adliye mahkemeleri hukuk dairelerinin farklı yönde kararlar vermesinden ve fiiliyatta bu konuda iki ayrı uygulamanın ortaya çımasından kaynaklanmaktadır. Sakarya Bölge Adliye Mahkemesi Hukuk Daireleri Başkanlar Kurulu bu konuda uyuşmazlı̆̆ın giderilmesi için Yargıtay’n ilgili dairesinden karar alınmasını talep etmiştir. Yargıtay 23. Hukuk Dairesi ise görüş ayrılıklarını, ticari nitelikteki alacaklar için yapılan takipteki itirazın iptali davalarının zorunlu arabuluculuğa tabi olduğu yönünde gidermiştir.

\section{MERCI KARARLARI}

\section{A. SAKARYA BÖLGE ADLIYE MAHKEMESI 7. HUKUK DAIRESI'NIN KARARI}

Davacının davalı kooperatiften olduğunu iddia ettiği alacağı için yapmış olduğu icra takibine kooperatif tarafından itiraz edilmesi üzerine açılan itirazın iptali davası, davaya bakan ilk derece mahkemesince dava açılmadan önce arabuluculuğa başvurulmadığı gerekçesiyle dava şartı yokluğundan reddedilmiş; bu karara karşı davacı tarafından istinafa başvurulmuştur. İtirazın iptali davasının dava şartı arabuluculuğa tabi olmadığı yönünde karar veren Sakarya Bölge Adliye Mahkemesi 7. Hukuk Dairesi’nin ${ }^{1}$ itirazın iptali davasının hukuki niteliği ve zorunlu arabuluculuğa elverişliliğiyle ilgili yapmış olduğu ayrıntılı değerlendirmelerin özeti aşağıdaki gibidir:

- 2004 Sayılı İcra ve İflas Kanunu’nun ${ }^{2}$ 67/1 maddesindeki davada ne bir şeyin verilmesi veya yapılması, ne de yapılmaması talep edilmektedir. Bu davada, iki husus birden tespit edilecektir. Birincisi, davacının alacağının olduğu, ikincisi ise borçlunun itirazının haksız olduğudur. Burada kanun koyucunun yasallaştırdığı bir "müspet tespit" davası bulunur.

- İtirazın iptali davası açılmasında amaç, itiraz ile kanun gereğince kendiliğinden durmuş olan takibin devamını sağlamaktır. Borçlu tarafından alacaklı aleyhine açılan menfi tespit davası alacaklı lehine sonuçlansa dahi ilamsız takibe devam edilemez.

- Hükmün infazı yönünden de her iki dava [eda (tahsil) ve tespit davaları] arasında farklar vardır. Borçlunun itirazı üzerine takip duracaktır (İIK m. 66). Alacaklı, nasıl ki itirazın kaldırılması için merciye müracaat edip lehine karar aldığı takdirde takibe kaldığı yerden devam edebilecekse (İ̈K. m. 69/1, m.78/1), itirazın iptaline dair mahkemeden karar alınınca da ilam icra memuruna ibraz edilerek derdest olan ilamsız icra takibine devam olunacaktır. Oysa, tahsile dair ilam alındığı takdirde artık ilamsız takip söz konusu olamayacak, İIK' nın 32 ve devamı maddeleri gereğince ilamların icrası yoluna başvurmak gerekecektir Her iki takip yolu ve usulü değişiktir. Örneğin, birinde ödeme emri, diğerinde icra emri çıkmaktadır. İlamsız takipte borçlu her türlü

1 Sakarya BAM 7. Hukuk Dairesi, E. 2020/808, K. 2020/670, T. 17.6.2020 (bkz: www.lexpera.com. E.T. 02.01.2020).

2 RG 19.6.1932, S. 2128. Çalışmada bundan sonra kısaca "İ̈K” olarak kullanılacaktır. 
itirazı ileri sürebilir; icra emrine karşı ise sadece ödeme, zamanaşımı ve ihmal nedeniyle itiraz edilebilir.

- İ̀tirazın iptali davasını karakterize eden öğeler, borçlunun, itirazının iptaline ve takibin devamına karar verilmesiyle icra inkâr tazminatına çarptırılmasıdır (İ̇K m. 67). Bu boyutları itibariyle sözü edilen dava, takip prosedürünün bütünü içinde yer alan, esas itibariyle onun ayrılmaz bir parçasını oluşturan ve takibin işleyişini sağlamaya yönelmiş bulunan bir dava konumunda bulunduğu için dava şartı arabuluculuk kurumunun kapsamın dışında kalır.

Sakarya Bölge Adliye Mahkemesi 7. Hukuk Dairesi bu değerlendirmeler neticesinde istinaf başvurusunun kabulüyle ilk derece mahkemesinin kararının 6100 sayılı Hukuk Muhakemeleri Kanunu’nun $^{3}$ 353/1-a-3 ve 4 bentleri gereğince kaldırılmasına, davanın yeniden görülmesi için ilk derece mahkemesine gönderilmesine karar vermiştir.

\section{B. ANKARA BÖLGE ADLIYE MAHKEMESI 23. HUKUK DAIRESI'NIN KARARI4}

Kooperatif aidat alacağının tahsili için başlatılan icra takibindeki itirazın iptaline ilişkin talep ilk derece mahkemesince davanın dava şartı olan arabuluculuğa başvurulmadan açılması gerekçesiyle usulden reddedilmiştir. İstinaf başvurusu üzerine Ankara Bölge Adliye Mahkemesi 23. Hukuk Dairesi: “6102 sayılı Türk Ticaret Kanunu’nun 5/A (Ek: 06/12/2018 - 7155 S.K./20 md.) maddesinin birinci fikrasında geçen "Bu Kanunun 4 üncü maddesinde ve diğer kanunlarda belirtilen ticari davalardan, konusu bir miktar paranın ödenmesi olan alacak ve tazminat talepleri hakkında dava açılmadan önce arabulucuya başvurulmuş olması dava şartıdır." hükmünü haiz olup 1163 sayılı Kooperatifler Kanununun 99. maddesinde yer alan "Bu kanunda düzenlenen hususlardan doğan hukuk davaları, tarafların tacir olup olmadıklarına bakılmaksızın ticari dava sayılır." hükmü gereğince görülmekte olan kooperatif aidatının tahsili için başlatılan icra takibine itirazın iptali istemli dava açılmadan önce arabulucuya başvurulması dava şartıdır." demek suretiyle istinaf başvurusunun esastan reddine karar vermiştir 5 .

\section{YARGITAY 23. HUKUK DAIRESI'NIN KARARI}

Ticari dava niteliğindeki itirazın iptali davalarında dava açılmadan önce arabuluculuğa başvurma dava şartının uygulanması konusunda çeşitli bölge adliye mahkemeleri tarafından farklı kararlar verildiğinden hareketle Sakarya Bölge Adliye Mahkemesi Hukuk Daireleri Başkanlar Kurulu tarafından benzer olaylarda bölge adliye mahkemesi hukuk dairelerince verilen kesin nitelikteki kararlar arasında uyuşmazlık bulunması hâlinde bu uyuşmazlığın giderilmesi için dosyanın ilgili hukuk dairesi olan Yargıtay 23. Hukuk Dairesi’ne gönderilmesine karar verilmiştir.

3 RG 04.02.2011, S. 27836. Çalışmada bundan sonra kısaca "HMK” olarak kullanılacaktır

4 Karşıt merci kararı olarak neden yalnızca Ankara BAM 23. Hukuk Dairesi kararına yer verdiğimiz çalışmamızın IV. başlığında incelenmiştir.

5 Ankara BAM 23. Hukuk Dairesi, E. 2019/2420, K. 2019/1789, T. 6.11.2019 (Yayınlanmamış karar). 
Yargıtay 23. Hukuk Dairesi kararında aşağıdaki değerlendirmelere yer vermiştir6:

- Doktrinde farklı görüşler olmakla birlikte İcra İflas Kanunu’nun 67. maddesinde düzenlenmiş itirazın iptali davası bir para alacağının tahsili için girişilen ilamsız icra takibine karşı itirazda bulunan borçlunun itirazının hükümden düşürülerek, bir başka deyişle itirazın haksız olduğunun tespiti ve alacağın miktarının belirlenmesi suretiyle davacının alacağına kavuşmasını sağlayan takip hukukuna özgü bir tahsil davasıdır.

- I İirazın iptali davasının açılması halinde aynı alacakla ilgili genel hükümlere göre alacak davası açılmasında hukuki yarar olmadığı, itirazın iptali davası süresinde açılmamış ise veya başka bir nedenle alacaklı davaya alacak davası olarak devam etmek istediği takdirde itirazın iptali davasını ıslah suretiyle alacak davasına dönüştürebileceği, itirazın iptaline karar verilmesi halinde ilamın icra dairesine ibrazı suretiyle duran icra takibine devam edilerek alacağın tahsilinin sağlanabileceği gözetildiğinde, itirazın iptali davasının alacağın tahsilini sağlama amacına hizmet ettiği anlaşılacaktır.

- Yine itirazın iptali davasında alacaklının davadan kısmen veya tamamen feragat etmek suretiyle alacağından vazgeçebileceği, buna karşılık borçlunun yargılama sırasında alacak tutarını kısmen veya tamamen ödemesinin geçerli olduğu, ödeme tutarınca borcun sona ereceği, borçlunun icra takibine yaptığı itirazdan kısmen veya tamamen vazgeçmek suretiyle alacaklının alacağını kısmen veya tamamen kabul edebileceği gözetildiğinde itirazın iptali davasının 6325 sayılı Arabuluculuk Kanunu'nun aradığı anlamda tamamen taraf iradelerinin hâkim olduğu ve tarafların dava konusu alacak hakkında serbestce tasarrufta bulunabileceği dava türlerinden olduğu herhangi bir kuşku ve duraksamaya yol açmayacak şekilde açıktır.

- $\quad \mathrm{Bu}$ nedenlerle ticari uyuşmazlıklarda zorunlu arabuluculuğu öngören 7155 sayılı Kanun’un 20. maddesiyle eklenen Türk Ticaret Kanunu’nun 5/A maddesinin para alacağının tahsilini amaçlayan uyuşmazlıklar hakkında tarafların serbestce tasarruf etme imkanına sahip olduğu gözetilerek bu uyuşmazlıkları bir alternatif çözüm yöntemi olarak arabuluculuk yoluyla çözmeyi amaçladığı, bu şekilde daha az zaman, daha az emek ve masrafla alacağın tahsili amacına ve tarafların alacak miktarı üzerinde serbestçe anlaşabilmelerine ve tasarrufta bulunabilmelerine imkân sağlamak istediği gözetildiğinde, ticari dava niteliğindeki itirazın iptali davalarının zorunlu arabuluculuğa tâbi olduğu ve bu nedenle başvuru konusu Bölge Adliye Mahkemesi Hukuk Daireleri arasındaki içtihat farklılı̆̆ının ticari nitelikteki itirazın iptali davalarının zorunlu arabuluculuğa tâbi olduğu ve davadan önce arabulucuya başvurulmasının dava şartı olduğu yönünde birleştirilmesi gerekmiş, bölge adliye mahkemeleri daireleri arasındaki uyuşmazlığın bu şekilde giderilmesine karar verilmiştir.

Yukarıda belirtilen gerekçeler doğrultusunda Yargitay 23. Hukuk Dairesi bölge adliye mahkemesi hukuk daireleri arasındaki içtihat farklılığını ticari dava niteliğindeki itirazın iptali davalarının

6 Yargitay 23. Hukuk Dairesi, E. 2020/1943, K. 2020/4052, T. 04.12.2020. (bkz: www.lexpera.com. E.T: 10.01.2021) 
zorunlu arabuluculuğa tâbi olduğu ve davadan önce arabulucuya başvurulmasının dava şartı olduğu yönünde birleştirmiş ve uyuşmazlı̆̆ın bu şekilde giderilmesine karar vermiştir.

\section{HUKUKI SORUN}

Yukarıda yer verilen kararları incelediğimizde problemli iki husus görülmektedir. Ele alınması gereken konular Yargıtay 23. Hukuk Dairesi’nin kararının bağlayıcılı̆̆g ile ticari dava niteliğindeki

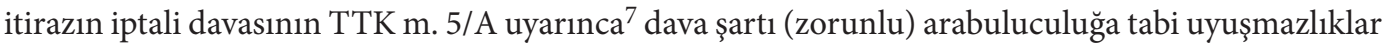
kapsamında değerlendirilip değerlendirilemeyeceğinden ibarettir.

\section{YARGITAY 23. HUKUK DAIRESI'NIN KARARININ NITELIK VE BAĞLAYICILIK YÖNÜNDEN DEĞERLENDIRILMESi}

Uyuşmazlığın esasını değerlendirmeden önce kanaatimizce ilk olarak Yargıtay 23. Hukuk Dairesi’nin vermiş olduğu kararın niteliği ve kapsam bakımından bağlayıcılığı ele alınmalıdır. Bu noktada öncelikli olarak bölge adliye mahkemeleri hukuk daireleri kararları arasında uyuşmazlık çıktığı zaman bu uyuşmazlığın ne şekilde giderileceğini gösteren kanuni düzenlemeler incelenmelidir. Adlî Yargı İlk Derece Mahkemeleri ile Bölge Adliye Mahkemelerinin Kuruluş, Görev ve Yetkileri Hakkında 5235 sayılı Kanun ${ }^{8}$ m. 35/1-3’te, Bölge Adliye Mahkemesi Hukuk Daireleri Başkanlar Kurulunun benzer olaylarda bölge adliye mahkemesi hukuk veya ceza dairelerince verilen kesin nitelikteki kararlar arasında ya da bu mahkeme ile başka bir bölge adliye mahkemesi hukuk veya ceza dairelerince verilen kesin nitelikteki kararlar arasında uyuşmazlık bulunması hâlinde bu uyuşmazlığın giderilmesini gerekçeli olarak istemeleri üzerine, kendi görüşlerini de ekleyerek Yargıtay'dan bu konuda bir karar verilmesini isteyebileceği düzenlenmiştir.

Konuyla ilgili olarak 2797 sayılı Yargıtay Kanunu'nda ${ }^{9}$ da çeşitli düzenlemeler bulunmaktadır. İstinaf sistemine hazırlık aşamasında yapılan kanuni düzenlemeler çerçevesinde 26.9.2004 tarihinde Yargıtay Kanunu m. 15’te değişiklik yapılmış ve m. 15/1'in 2. bendine yeni bir (a) alt bendi eklenmişti. $\mathrm{Bu}$ düzenlemeye göre aynı veya farklı yer bölge adliye mahkemelerinin kesin olarak verdikleri kararlar bakımından hukuk daireleri arasında veya ceza daireleri arasında uyuşmazlık bulunursa, bu hususların Hukuk ve Ceza Genel Kurullarınca içtihatların birleștirilmesi yoluyla kesin olarak karara bağlanacağı düzenlenmişti. Görüldüğü üzere bu düzenlemeyle bölge adliye mahkemeleri arasında ortaya çıkan içtihat farklılıklarının da tıpkı Yargıtay daireleri arasındaki görüş farklılıklarında olduğu gibi içtihadı birleştirme yoluyla giderileceği öngörülmekteydi ${ }^{10}$. Buna karşılık 2017 tarihli

7 İlgili madde șu șekildedir: “(1) Bu Kanunun 4 üncü maddesinde ve diğer kanunlarda belirtilen ticari davalardan, konusu bir miktar paranın ödenmesi olan alacak ve tazminat talepleri hakkında dava açılmadan önce arabulucuya başvurulmuş olması dava şartıdır. (2) Arabulucu, yapılan başvuruyu görevlendirildiği tarihten itibaren altı hafta içinde sonuçlandırır. Bu süre zorunlu hâllerde arabulucu tarafindan en fazla iki hafta uzatılabilir."

$8 \quad$ RG 7.10.2004, S. 25606.

9 RG. 08.02.1983, S. 17953.

10 Muhammet Özekes, "İstinaf Sistemiyle Birlikte Hukuk Yargılamasında İçtihat Ayrılıklarının Giderilmesi”, Türkiye’de İstinaf Mahkemelerinin Kurulmasından Sonra Yargıtay’ın Rolü Konferansı, Ankara 2007, s. 147. 
696 sayılı OHAL KHK'sının ${ }^{11}$ 46. maddesi ile Yargitay Kanunu’nun 15. maddesinin birinci fikrasının (2) numaralı bendinin (a) alt bendi yürürlükten kaldırılmıştır. Dolayısıyla "Hukuk ve Ceza Genel Kurullarının görevleri” başlıklı 15. maddenin güncel halinde, yalnızca Yargıtay hukuk daireleri veya ceza daireleri arasında içtihat uyuşmazlıkları bulunması ile Yargıtay dairelerinden birinin yerleşmiş içtihadından dönmek istemesi ya da benzer olaylarda birbirine uymayan kararlar vermiş bulunması durumunda bunların içtihatların birleştirilmesi yoluyla kesin olarak karara bağlanacağı düzenlenmektedir (Yargitay Kanunu m. 15/2. b-c).

Yargitay Kanunu m. 15'ten ilgili alt bendi kaldıran 2017 tarihli 696 sayılı OHAL KHK’sının 92. maddesi ile 5235 sayılı Kanun'un m. 35. maddesinin ikinci fikrasına da bir ekleme yapılmış, yeni düzenlemede benzer olaylarda bölge adliye mahkemesi hukuk veya ceza dairelerince verilen kesin nitelikteki kararlar arasında ya da bu mahkeme ile başka bir bölge adliye mahkemesi hukuk veya ceza dairelerince verilen kesin nitelikteki kararlar arasında uyuşmazlık bulunması ve bu uyuşmazlığın giderilmesinin gerekçeli olarak istenmesi üzerine, bu istemlerin ceza davalarında Yargıtay Cumhuriyet Başsavcılığı’na, hukuk davalarında ise ilgili hukuk dairesine iletileceği ve uyuşmazlığın giderilmesine ilişkin olarak dairece bu fikra uyarınca verilen kararların kesin olacă̆ $ı$ düzenlenmiştir. Anlaşıldığı üzere bu düzenlemeyle bölge adliye mahkemeleri daireleri arasındaki uyuşmazlı̆̆ın nasıl giderileceğiyle ilgili usul Yargıtay Kanunu'ndan alınarak 5235 sayılı Kanun'a dahil edilmiş ve muhtemeldir ki alakalı düzenlemelerin bir arada olması amaçlanmıştır.

Özetle belirtilmelidir ki güncel haliyle bölge adliye mahkemeleri daireleri arasında çıkan uyuşmazlıklar talep üzerine ilgili Yargıtay dairesi tarafından kesin olarak giderilecek; içtihadı birleştirme kararına konu olmayacaktır. Peki bu kesin olarak karara bağlanan uyuşmazlık hangi kapsamda bağlayıcı olacaktır? Konuyu daha açık ele almamız bakımından Yargıtay içtihadı birleştirme kararlarının niteliği ve bağlayıcılık gücüne bakmak gerekir. Yargıtay Kanunu m. 45/5’e göre içtihadı birleştirme kararları benzer hukuki konularda Yargıtay genel kurullarını, dairelerini ve adliye mahkemelerini bağlar ${ }^{12}$. Peki bölge adliye mahkemeleri daireleri arasındaki uyuşmazlığın Yargıtay Dairesi tarafından kesin olarak giderilmesi durumunda diğer daireler ve ilk derece mahkemeleri bakımından aynı bağlayıcılıktan söz edebilir miyiz? Bu noktada bölge adliye mahkemeleri daireleri arasındaki görüş uyuşmazlıklarını gidermekle tayin edilen Yargıtay dairelerinin iş bölümü bakımından yalnızca belli bölge adliye mahkemeleriyle sınırlı tutulması, ele alınması gereken bir soru işareti olarak ortaya çıkmaktadır. Şöyle ki, ele aldığımız kararda Sakarya Bölge Adliye Mahkemesi Hukuk Daireleri Başkanlar Kurulunca uyuşmazlığın giderilmesi amacıyla Yargıtay’ın ilgili dairesinden karar alınması için yapılan başvuruda karşıt görüş olarak Ankara Bölge Adliye Mahkemesi 23. Hukuk Dairesi’nin 2019/2420 E. ve 2019/1789 K. sayılı kararının yanında aynı zamanda Adana Bölge Adliye Mahkemesi 9. Hukuk Dairesi 2019/1538 E. ve 2020/234 K.; Ankara Bölge Adliye Mahkemesi 22. Hukuk Dairesi 2020/105 E. ve 2020/494 K.; Trabzon Bölge Adliye Mahkemesi 4. Hukuk Dairesi 2020/318 E. ve 2020/316 K.; İstanbul Bölge Adliye Mahkemesi 12. Hukuk Dairesi 2019/1376 E. ve 2019/1059 K.; İstanbul Bölge Adliye Mahkemesi 13. Hukuk Dairesi 2020/39 E. ve 2020/45 K.; İzmir Bölge Adliye

11 RG 24.12.2017, S. 30280.

12 Adliye mahkemeleri kavramını adli yargı mahkemeleri olarak değerlendirerek bu üst başlığın içine hem ilk derece mahkemelerini hem de bölge adliye mahkemelerini dahil etmek gerekir. 
Mahkemesi 17. Hukuk Dairesi 2020/246 E. ve 2020/516 K.; Samsun Bölge Adliye Mahkemesi 3. Hukuk Dairesi 2019/2035 E. ve 2020/213 K.; Ankara Bölge Adliye Mahkemesi 23. Hukuk Dairesi $2019 / 2420$ E. ve 2019/1789 K. sayılı kararlarında da ticari nitelikteki icra takibinde vaki itirazın iptali istemli davaların zorunlu arabuluculuğa tabi olduğu, bu nedenle TTK’nın 5/A maddesi uyarınca dava açılabilmesi için arabulucuya başvurulmuş olmasının dava şartı olduğu görüşünün benimsendiği belirtilmiştir. Yargıtay 23. Hukuk Dairesi ise uyuşmazlığın giderilmesi istemi üzerine başvuruyu yalnızca iş bölümü itibariyle görevi içerisinde olan ve kooperatifler hukukunu ilgilendiren Sakarya Bölge Adliye Mahkemesi 7. Hukuk Dairesi'nin 2020/808 E. ve 2020/670 K. sayılı kararı ile Ankara Bölge Adliye Mahkemesi 23. Hukuk Dairesi'nin 2019/2420 E. ve 2019/1789 K. sayılı kararıyla sinırlı bir biçimde incelemiş, Sakarya Bölge Adliye Mahkemesi Hukuk Daireleri Başkanlar Kurulu’nun başvurusunda zikredilen diğer bölge adliye mahkemeleri kararlarını ise dairenin iş bölümü itibariyle görevi kapsamında olmadığı için incelemenin kapsamı dişında tutmuştur. Bu aşamada inceleme kapsamı dışında tutulan diğer bölge adliye mahkemeleri hukuk dairelerinin Yargıtay 23. Hukuk Dairesi'nin bu konuda verdiği kararla bağlı olup olmayacağı sorusunu sormak gerekir. 5235 sayılı Kanun m. 35/2’te daireler arasındaki uyuşmazlığın kesin olarak çözüleceği belirtilmekle birlikte bu kararın diğer bölge adliye mahkemesi hukuk daireleri ve ilk derece mahkemeleri bakımından bağlayıcı olacağıyla ilgili herhangi bir ibareye yer verilmemiştir.

Kanaatimizce Yargitay Kanunu m. 15'in eski düzenlemesi bölge adliye mahkemeleri daireleri arasındaki uyuşmazlıkların giderilmesi bakımından daha isabetli bir düzenleme teşkil etmektedir. Zira maddenin eski hali Yargıtay dairesi ya da bölge adliye mahkemeleri dairesi fark etmeksizin daireler arasındaki görüş uyuşmazlıklarının içtihadı birleştirme yoluyla çözülmesini öngörmekteydi. Eski düzenlemenin kanaatimizce birkaç noktada avantajı bulunmaktadır. İlk olarak bölge adliye mahkemeleri daireleri arasında içtihat farklılığı bulunan konularda uyuşmazlığı giderecek Yargitay dairesinin kendi iş bölümüyle sınırlı inceleme yapması, diğer bölge adliye mahkemelerinin görüşlerinin değerlendirme harici tutulmasına ve belki de eksik inceleme sonucu karar verilmesine sebep olabilir. Oysa Yargıtay içtihadı birleştirme kararları herhangi bir iş bölümü sınırlamasına tabi olmayan Yargitay Hukuk Genel Kurulu tarafindan verilmektedir (Yargitay Kanunu m. 15). Bu sayede görüş ayrılığının giderilmesi istemine konu kararlar bakımından herhangi bir konu sınırlaması yapılmaksızın görüş ayrılığı yaşayan tüm Yargıtay daire kararlarına yer verilmekte ve bu sebeple karara varılırken ulusal boyutta ve kapsayıcı bir değerlendirme yapılmaktadır. Nitekim Yılmaz içtihadı birleştirme kararlarında lehte ve aleyhte her türlü görüşe yer verildiğine ve bu görüşlerin geniş katılımla incelendiğine işaret ederek, bu kararların uygulamacılara yol gösteren ve hukuku daha ileri götüren nitelikte olduğunu ifade etmiştir ${ }^{13}$. İkinci olarak içtihadı birleştirme kararlarının tüm mahkemeler bakımından bağlayıcı olduğu ve derhal bütün adliye mahkemelerine ve Cumhuriyet savcılıklarına gecikmeksizin duyurulacağı açıkça kanunen düzenlendiği için (bkz: Yargitay Kanunu m. 45/6) ilgili kararın uygulanma gücü bakımından herhangi bir tereddüt de ortaya çıkmamaktadır. Son olarak içtihadı birleştirme kurumu ülkemizde hukukun birliğinin sağlanması için uzun yıllardır uygulanan, tanınan ve yerleşmiş uygulaması olan bir kurum olduğu için hukuk sistemimize yeni

13 Ejder Yılmaz, “İçtihadı Birleştirme’ veya 'Adaletteki Çelişkiye Son Verme’ İhtiyacı”, Ticaret Hukuku ve Yargıtay Kararları Sempozyumu XVIII, Banka ve Ticaret Hukuku Araştırması Enstitüsü, 2010, s. 17. 
dahil olan istinaf aşamasındaki karar uyuşmazlıklarının giderilmesi aşamasında da bu bilindik kuruma başvurulması ortaya çıkabilecek soru işaretlerini önlemekte emin bir araç olacaktır. Zira içtihat birliğinin tereddüte yer kalmayacak bir şekilde sağlanması, tüm ülkede hukuk kurallarının aynı şekilde uygulanması için son derecede önemlidir.

Bu gerekçelerle mümkünse bölge adliye mahkemeleri hukuk daireleri arasındaki görüş ayrilıklarının içtihadı birleştirme yoluyla giderileceğini öngören eski düzenlemeye geri dönülmesinin uygun olacağ 1 kanaatindeyiz Bu mümkün değilse de 5235 sayılı Kanun m. 35/2’te bir değişiklik yapılarak bölge adliye mahkemesi hukuk ve ceza daireleri arasında çıkan uyuşmazlıkların kesin olarak çözüleceği ibaresinin yanına, bu kararın diğer mahkemeler bakımından da bağlayıcı olacağının eklenmesinin ve uyuşmazlık giderilmesi aşamasında Yargıtay dairelerinin iş bölümüyle sınırlı kalınmaksızın görüş ayrılı̆̆ına konu olan diğer bölge adliye mahkeme kararlarının da incelenmesinin uygun olacağ kanaatindeyiz.

\section{ITTiRAZIN IPTALI DAVASININ ZORUNLU ARABULUCULUĞA TABi OLUP OLMADIĞININ DEĞERLENDIRILMESI}

\section{A. itiRAZIN iptali daVASININ HUKUKi NITELIĞi}

İtiraz üzerine duran ilamsız takibe devam edilebilmesi için alacaklıya sunulan imkanlardan biri İIK m. 67'de düzenlenen itirazın iptali davasıdır. Takip talebine itiraz edilen alacaklı, itirazın tebliği tarihinden itibaren bir sene içinde mahkemeye başvurarak genel hükümler dairesinde alacağının varlığını ispat suretiyle itirazın iptalini dava edebilir. Dava şartı arabuluculuğa tabi alacak ve tazminat talepleri için yapılan icra takiplerindeki itirazın iptali davalarının da zorunlu arabuluculuğa tabi olup olmayacağını değerlendirmek için öncelikli olarak itirazın iptali davasının hukuki niteliğini ele almak gerekir.

İtirazın iptali davasının hukuki niteliği doktrin tarafından görüş birliğine varılamayan ve uygulamada da farklı kararlar çımasına sebep olan bir konudur. Bu zamana kadar itirazın iptali davasıyla ilgili birkaç temel yaklaşımın olduğu söylenebilir. Bir görüş, itirazın iptal davasını klasik bir eda davası olarak nitelendirmektedir. Buna göre itirazın iptali davası alacağın tahsili talebini de kapsar. Davacı hem itirazın iptal edilmesini hem de alacağın tahsil edilmesini istediği için bu dava takip hukukunda da sonuç doğuran bir eda davası teşkil eder ${ }^{14}$. Alacaklının alacağına kavuşmak için açacağı eda

14 Baki Kuru, İcra ve İflas Hukuku, C. I, 3. Baskı, Evrim Dağıtım, İstanbul 1988; s. 280-281; Necmettin Berkin, Tatbikatçlar İçin İcra Hukuku Rehberi, İstanbul 1980, s. 421-422; Burhan Gürdoğan, İcra Hukuku Dersleri, Ajans Türk Matbaası, Ankara 1970, s. 38; İlhan E. Postacıŏlu, İcra Hukuku Esasları, İstanbul Üniversitesi Yayınları, İstanbul 1969, s. 18; İlhan E. Postacıoğlu/Sümer Altay, İcra Hukuku Esasları, 5. Bası, 2010, s. 224-225; Ramazan Arslan/Ejder Yılmaz/Sema Taşpınar Ayvaz/Emel Hanağası, İcra ve İflas Hukuku, 5. Baskı, Yetkin Yayınları, Ankara 2019, s. 175 ; Ergun Önen, İnşai Dava, Olgaç Matbaası, Ankara 1981, s. 136; Abdurrahim Karslı, İcra ve İflas Hukuku, 3. Baskı, Alternatif Yayınevi, İstanbul 2014, s. 22; Murat Erdem, İcra ve İflas Hukukunda İtirazm İptali Davası, Ankara Üniversitesi Sosyal Bilimler Enstitüsü, Yayınlanmamış Doktora Tezi, Ankara 2010, s. 21. 
davasını ödeme emrine itirazın kendine tebliğinden itibaren bir yıllık süre içerisinde açması durumunda bu dava otomatik olarak itirazın iptali davası adını alır. ${ }^{15}$

Diğer bir görüş itirazın iptali davasını bir tespit davası olarak nitelendirir. Çağa’ya göre itirazın iptali davasında mahkeme alacağın sabit olduğunu tespit ederse itirazın iptaline karar verecektir. Duran takibe devam edebilmek için bu kadarı yeterlidir ve davacı mahkemeden yalnızca bu kadarını istemektedir. Davacının ayrıca bir tahsil talebi yoktur. Bu sebeple itirazın iptali kararı alacaklının alacağının varlığını tespit eden müspet bir tespit hükmüdür ${ }^{16}$.

Son olarak bazı yazarlarca itirazın iptali davası spesifik olarak belli bir dava türüne dahil edilmemekle birlikte, icra iflas hukukuna özgü bir dava ya da icra iflas hukukuna özgü bir tahsil davası olarak nitelendirilmiştir. Buna göre itirazın iptali davasının temel amacı itiraz üzerine duran takibe devam edilmesidir ve itirazın iptali halinde alacağın tahsiline ilişkin bir ilam ortaya çıkmamaktadır. İtirazın iptali yanında yargılama giderlerine ve icra inkâr tazminatına hükmedilmesi ise eda hükmü teşkil $\operatorname{eder}^{17}$.

İsviçre hukukuna baktığımızda itirazla duran takibe devam edilebilmesi için takibin kesin veya geçici olarak kaldırılması kararı (SchKG ${ }^{18}$ Art. 80-84) ya da genel veya idari mahkemede alacağın tahsiline ilişkin bir ilamın alınması gerektiği düzenlenmiştir. Bizdeki itirazın iptali davasına denk gelen SchKG Art. 79'da düzenlenen Anerkennungsklage, alacağın tahsiline ve itirazın bertaraf edilmesine yönelen maddi anlamda bir eda davası olarak kabul edilmektedir ${ }^{19}$.

\section{B. TTK m. 5/A DÜZENLEMESININ KAPSAM BAKIMINDAN DEĞERLENDIRILMESi}

İtirazın iptali davasının TTK m. 5/A kapsamında kalıp kalmadığını değerlendirebilmek için öncelikle ilgili maddenin kapsamı ve sınırları ele alınmalıdır. 7155 sayılı Kanun ${ }^{20}$ ile TTK m. 5'den sonra

15 Ejder Yılmaz, “İtirazın İptali Davasının Hukuki Niteliği”, Prof. Dr. Saim Üstündă̆ Armağanı, Adalet Yayınevi, Ankara 2009, s. 608.

16 Tahir Çağa, “Ödeme Emrine İtirazın İptali Davasına Dair”, BATİDER, Ankara 1976, C. VIII, S. 3 , s. 24 vd. Bu yönde diğer görüşler için bkz: Talih Uyar, İcra Hukukunda İtiraz, 2. Baskı, Manisa 1990, s. 312-313; Yavuz Okçuoğlu, "İcra Hukukunda İtirazın İptali ve İnkâr Tazminatı", Bursa Barosu Dergisi, S.1980/11, s. 10-14.

17 Hakan Pekcanttez/Oğuz Atalay/ Meral Sungurtekin Özkan/Muhammet Özekes, İcra ve İflas Hukuku Ders Kitabı, 6. Baskı, Oniki Levha Yayınları, 2020, s. 111; Adnan Deynekli/Sedat Kısa, İtirazın İptali Davaları, Turhan Kitabevi, Ankara 2013, s. 82-83; Timuçin Muşul, İcra ve İflas Hukuku, C. I, Adalet Yayınevi, 5. Baskı, Ankara 2013, s. 380; Murat Atalı/ İbrahim Ermenek/Ersin Erdoğan, İcra ve İflas Hukuku, 3. Baskı, Yetkin Yayınları, Ankara 2020, s. 150; Gönen Eriş, "Ödeme Emrine İtirazın İptali Davası ve Bazı Sorunlar", ABD, Y. 1977, S. 5, s. 822-841; Süha Tanrıver, "Dava Şartı Arabuluculuk Üzerine Bazı Düşünceler", TBBD, Y. 2020, S. 147, s. 123; İbrahim Ermenek/Betül Azaklı Arslan, "İcra ve İflâs Hukuku Açısından Ticarî Davalarda Arabulucuya Başvuru Zorunluluğu (TTK m. 5/A)”, TBBD, Y. 2020, S. 148, s. 160.

18 İsviçre İcra İflas Kanunu, Alm. Bundesgesetz über Schuldbetreibung und Konkurs.

19 Jolanta Kren Kostkiewicz/Dominik Vock, Kommentar zum Bundesgesetz über Schuldbetreibung und Konkurs SchKG, 4. Auflage, 2017, Art. 79, Rn. 2-3; Dominik Vock/Danièle Meister-Müller, SchKG-Klagen nach der Schweizerischen ZPO, 2. Auflage, 2018, s. 116; Kâmil Yıldırım/Nevhis Deren Yıldırım, İcra ve Iflas Hukuku, 6. Baskı, Beta Yayınları, İstanbul 2015, s. 98.

20 Abonelik Sözleşmesinden Kaynaklanan Para Alacaklarına İlişkin Takibin Başlatılması Usulü Hakkında Kanun, RG 19.06.2018, S. 30630 . 
gelmek üzere eklenen 5/A maddesi: "Bu Kanunun 4 üncü maddesinde ve diğer kanunlarda belirtilen ticari davalardan, konusu bir miktar paranin ödenmesi olan alacak ve tazminat talepleri hakkında dava açılmadan önce arabulucuya başvurulmuş olması dava şartıdır" şeklindedir.

Maddede dava şartı arabuluculuğa tabi tutulacak uyuşmazlıklar için iki ana kritere yer verilmiştir ${ }^{21}$. İlk olarak TTK m. 5/A kapsamı ticari davalarla sınırlı tutulmuştur. Ticari davaların neler olduğuna ise TTK m. 4'te yer verilmiştir. Buna göre her iki tarafın da ticari işletmesiyle ilgili hususlardan doğan hukuk davaları ile tarafların tacir olup olmadığına bakılmaksızın TTK'da düzenlenen davalar ile yine anılan maddenin (a) ile (f) bendi arasında bahsedilen hususlardan doğan hukuk davaları ticari dava sayılmaktadır. Tarafların tacir olup olmadığına ve işin bir ticari işletmeyi ilgilendirip ilgilendirmediğine bakılmaksızın ticari sayılan davalar mutlak ticari davalar olarak adlandırılırken, her iki tarafın ticari işletmesiyle ilgili hususlardan doğan ve iki tarafı da tacir olan hukuk davaları da nispi ticari davalar olarak kabul edilmektedir ${ }^{22}$. Dava şartı arabuluculuğa tabi tutulma konusunda TTK m. 5/A düzenlemesine bakıldığında mutlak ticari davalar ile nispi ticari davalar arasında fark gözetilmemiştir ${ }^{23}$. Buna karşılık TTK m. 5/A’da yalnızca "ticari davalardan" bahsedildiği için, ticari nitelikteki çekişmesiz yargi işlerinin, geçici hukuki koruma tedbirlerinin ve icra takiplerinin madde kapsamına dâhil olmadığı anlaşılmaktadır²4 .

Anılan maddede ikinci olarak ticari davalardan, konusu bir miktar paranın ödenmesi olan alacak ve tazminat talepleri bakımından dava açılmadan önce arabulucuya başvurma zorunluluğunun geçerli olacağı ifade edilmiştir. Görülüyor ki kanun koyucu bu noktada ticari davalarda dava şartı arabuluculuğun kapsamını belirlerken dava konusunu belirleyici faktör olarak ele almıştır. Maddede yer verilen "konusu bir miktar paranın ödenmesi olan alacak ve tazminat talepleri" ile tam olarak neyin kastedildiğini tespit edebilmek için ise öncelikli usul hukukumuzda dava konusu kavramını hangi usul hukuku kurumlarına karşılık geldiği açığa kavuşturulmalı ve devam açıklamalar bu bağlamda yapılmalıdır.

Dava konusu kavramının açıklamak için özellikle karşılaştırmalı hukukta çeşitli teoriler geliştirilmiş ve hukukumuzda bu teoriler çerçevesinde görüş üretilmiştir ${ }^{25}$. Hukukumuzda daha azınlık bir

21 Anılan maddede yer verilen hususlar haricinde doğaldır ki ilgili uyuşmazlıkların 6325 sayılı Hukuk Uyuşmazlıklarında Arabuluculuk Kanunu m. 1/2 uyarınca arabuluculuğa elverişli olması da gerekir. İlgili madde şu şekildedir: "Bu Kanun, yabancılık unsuru taşıyanlar da dâhil olmak üzere, ancak tarafların üzerinde serbestçe tasarruf edebilecekleri iş veya işlemlerden doğan özel hukuk uyuşmazlıklarının çözümlenmesinde uygulanır. Şu kadar ki, aile içi șiddet iddiasını içeren uyuşmazliklar arabuluculuğa elverişli değildir."

22 Levent Börü/illker Koçyiğit, Ticari Dava, 2. Baskı, Ankara 2021, s. 28.

23 Ali Paslı, "Ticari İșletme ve Ticaret Şirketleri Bakımından Zorunlu Arabuluculuğun Değerlendirilmesi: Türk Ticaret Kanunu 5/A Maddesinin Yorumlanması”, Ticari Uyuşmazlıklarda Zorunlu Arabuluculuk (Editör: Ceyda Süral Efeçınar/ Mehmet Ertan Yardım), Ankara 2019, s. 15.

24 Türkiye Barolar Birliği, Ticari Uyuşmazlılarda Dava Şartı Olan Arabuluculukta Taraf Vekilliği El Kitabı, 2019, s. 20 (https://d.barobirlik.org.tr/2019/ticariuyusmazliklardaarabuluculukelkitabi/18/, E.T. 20.04.2021); Ermenek/Azakli Arslan, s. 138-139; Murat Atalı/Ersin Erdoğan, "Türk Ticaret Kanunu’nun 5/A Maddesi Çerçevesinde Menfi Tespit Davaları Sorunu", Çankaya Üniversitesi Hukuk Fakültesi Dergisi, Y. 2020, C. 5, S. 1, s. 208.

25 Çalışma kapsamımız itibariyle dava teorisinin tarihi gelişimi ve ortaya atılan teorilere burada yer verilemeyecektir. Konuyla ilgili ayrıntılı bilgi için bkz: Ejder Yılmaz, Medeni Yargılama Hukukunda Islah, 5. Baskı, Ankara 2021, s. 185 vd; Süha Tanriver, Medeni Usul Hukuku, C. I, 2. Baskı, Ankara 2018, s. 482 vd. 
şekilde yer bulan çift unsurlu dava konusu teorisine göre, dava konusu belirlenirken talep sonucuna ve vakıalara eşit derece ehemmiyet verilmelidir. Buna göre yalnızca mahkemeden talep edilen şeye göre değil, aynı zamanda o talebi haklı göstermek için ileri sürülen vakıalar kompleksi de dava konusu içinde değerlendirilmelidir ${ }^{26}$. Buna karşılık doktrinde ve uygulamamızda hakim görüş olan tek unsurlu dava teorisine göre ise dava konusu tespit edilirken yalnızca talep sonucuna dikkat edilmeli, tarafların ileri sürdüğü vakıalar dava konusu kapsamına alınmamalıdır ${ }^{27}$. Nitekim HMK'nın çeşitli düzenlemelerinde de dava konusu olarak doğrudan talep sonucuna işaret edildiği görülmektedir ${ }^{28}$.

$\mathrm{Bu}$ açıklamalardan sonra TTK m. 5/A düzenlemesini öncelikli olarak dava konusu olarak talep sonucuyla birlikte vakıaları esas alan çift unsurlu dava teorisi doğrultusunda yorumladığımızda, mahkemeden doğrudan bir miktar paranın ödenmesinin talep edilmediği, örneğin bir hukuki ilişkinin yokluğunun tespit edilmesinin istendiği, ancak dava konusuna vücut veren hayat olayının para alacağını ilgilendirdiği ticari nitelikteki uyuşmazlıklar bakımından dava şartı arabuluculuğun geçerli olacağı sonucu ortaya çıkmaktadır ${ }^{29}$. Başka bir deyişle çift vakıa teorisine göre talep sonucuyla birlikte vakıaları da dava konusuna dahil ettiğimiz takdirde, ticari dava niteliğindeki menfi tespit davalarını da dava şartı arabuluculuk kapsamında kalacaktır ${ }^{30}$. Kanaatimizce böyle bir kabul doktrin ve HMK'da tercih edilen ve artık yerleşik hale gelmiş diyebileceğimiz dava konusu sistemine aykırı düşmektedir ve TTK m. 5/A’da yer bulan düzenlemenin lafzını ve amacını adeta zorlayarak genişlettiği için isabetli değildir. Bu noktada usule ilişkin kuralların dar değil, amaca uygun bir şekilde geniş yorumlanması gerektiğini ileri sürerek tespit davalarının da TTK m. 5/A gereğince dava şartı arabuluculuk kapsamına dahil edilmesini savunan görüşe katılamamaktayız ${ }^{31}$.

26 Bu teorinin Türk hukukundaki destekçileri için bkz: Yavuz Alangoya/M. Kamil Yıldırım/Nevhis Deren Yıldırım, Medeni Usul Hukuku Esasları, 7. Baskı, Beta Basım Yayımı, İstanbul 2009, s. 222; Timuçin Muşul, Medeni Yargılama Hukukunda Terdit İlişkileri, 2. Basım, Ankara 2009, s. 102; Hamide Özden Özkaya-Ferendeci, Kesin Hükmün Objektif Sınırları, İstanbul 2009, s. 177.

27 Kuru, Usul, C. V, s. 4987; İlhan E. Postacıoğlu, Medeni Usul Hukuku Dersleri, 6. Baskı, İstanbul 1975, s. 232; Necip Bilge/ Ergun Önen, Medeni Yargılama Hukuku Dersleri, 3. Baskı, Ankara 1978, s. 692; Saim Üstündağ, İddia ve Müdafaanın Değiştirilme Yasă̆ı, 1967, s. 147; Murat Atalı, Pekcanıtez Usul, C. III, 15. Baskı, İstanbul 2017, s. 2068; Yılmaz, Islah, s. 192; Süha Tanrıver, Medeni Usul Hukukunda Derdestlik İtirazı, Ankara Üniversitesi Hukuk Fakültesi Yayınları, Ankara 1998; s. 81-83; Tanrıver, Usul, s. 491; Emel Hanağası, Davada Menfaat, Yetkin Yayınları, Ankara 2009, s. 124; Levent Börü, Dava Konusunun Devri, Yetkin Yayınlar1, Ankara 2012, s. 232-233.

28 Bkz: sulh hukuk mahkemelerinin görevi başlıklı HMK m. 4/1, dava konusunun devri başlıklı HMK m. 125, ihtiyari dava arkadaşlığının şartlarını düzenleyen HMK m. 57. Yine HMK m. 303’te kesin hükmün unsurlarından bahsederken kanun koyucu 1086 S. HUMK m. 237'de kullanılan müddeabih (dava konusu) kavramı yerine, talep sonucu kavramını tercih etmiş, yine kesin hükmün unsurları olarak "dava konusu” ile "dava sebebi (vakıalar)”ı açıkça ayrı iki unsur olarak zikretmiştir. Böylelikle dava sebebini (vakıaları), dava konusundan bağımsız ve ayrı olarak bir kesin hüküm unsuru olarak ifade etmiştir. Bkz: Yılmaz, Islah, s. 190; Börü, s. 233.

29 Nitekim Budak dava konusunu belirlemeye yönelik ileri sürülen çift unsurlu teoriye uygun düşecek bir yorumla TTK m. 5/A'da ifade edilen "alacak ve tazminat taleplerinden" bahsedilirken talep sonucunun değil, dava sebebi (vakıaların) da dikkate alınması gerektiğini ileri sürmüştür. Yazara göre bu doğrultuda ticari uyuşmazlıklardaki menfi tespit davaları ile itirazın iptali davaları zorunlu arabuluculuğa tabi olmalıdır ve böyle bir yorum tarzı arabuluculuğu yaygınlaştırma yönündeki iradeye de uygun düşecektir. Bkz: Ali Cem Budak, “Ticari Davalarda Dava Şartı Olarak Arabuluculuk”, MİHDER, Y. 2019, C. 15, S. 42, s. 33.

30 Budak, s. 33; Nesibe Kurt Konca, “Ticari Uyuşmazlıklarda Dava Şartı (Zorunlu) Arabuluculuk”, SETA Perspektif, Y. 2018, S. 225 , s. .

31 İlker Koçyiğit/Alper Bulur, Ticari Uyuşmazlıklarda Dava Şartı Arabuluculuk, Ankara 2019, s. 141-142. 
Gerçekten de kanun koyucu 6325 Sayılı Hukuk Uyuşmazlıklarında Arabuluculuk Kanunu ${ }^{32}$ m. 1/2‘ de arabuluculuğun uygulama alanının geniş olması için arabuluculuğa elverişli alanları tarafların üzerinde serbestçe tasarruf edebilecekleri iş veya işlemlerden doğan özel hukuk uyuşmazlıkları olarak belirtmiş, bilinçli olarak madde kapsamını geniş tutmuştur. Eğer kanun koyucu ticari uyuşmazlıklarda dava şartı arabuluculuk uygulamasının da daha geniş bir alana yayılmasını istemiş olsaydı, TTK m. 5/A düzenlemesini bu anlayışa uygun bir şekilde kaleme almayı tercih edebilirdi ${ }^{33}$. Maddenin güncel halinden menfi tespit davalarının dava şartı arabuluculuğa tabi tutulacağı gibi bir sonucun çıkarılamayacağı, bu yönde bir irade varsa bu hususla ilgili mutlaka bir kanuni düzenleme yapılması gerektiği kanaatindeyiz ${ }^{34}$. Yine dava şartı (zorunlu) arabuluculuğun HUAK m. 3’te belirtilen ve arabuluculuğun temel ilkelerinden olduğu ifade edilen iradilik ilkesine tezat teşkil ettiğini ve bu yönüyle mahkemeye erişim hakkını belli ölçüde sınırlandırdığını düşünürsek, ihtiyari arabuluculuğa nazaran istisnai bir yerde duran dava şartı arabuluculuk düzenlemelerinin geniş değil, bilakis dar yorumlanmasının daha uygun olacağı ifade edilmelidir ${ }^{35}$.

32 RG. 22/6/2012, S. 2833.Çalışmada kısaca "HUAK” olarak kullanılacaktır.

33 Çiğdem Yazıcı Tiktık, “Ticari Davalarda Dava Şartı Olarak Arabuluculuk Uygulamasının Temel İlkeler Bakımından Değerlendirilmesi”, Ticari Uyuşmazlıklarda Zorunlu Arabuluculuk (Editör: Ceyda Süral Efeçınar/Mehmet Ertan Yardım), Ankara 2019, s. 116.

34 Bu yönde bkz: Muhammet Özekes/Pınar Çiftçi, "Menfî Tespit Davalarını Zorunlu Arabuluculuğa Dahil Saymanın Gereksizliği Üzerine”, TBBD, C. 33, S. 148, Y. 2020, s. 127. Nitekim ticaret nitelikteki menfi tespit davalarında 7155 Sayılı Kanunla 6102 Sayılı TTK’na eklenen 5/A maddesi uyarınca arabuluculuğa başvurunun dava şartı olup olmadığ 1 hususunda bölge adliye mahkemeleri hukuk daireleri kararları arasında çelişki bulunduğu belirtilerek bu çerçevede uyuşmazlığın giderilmesi için ilgili Yargıtay Dairesi'ne yapılan başvuru sonucunda, Yargıtay 19. HD tarafından ilgili TTK 5/A maddesinin genişletici bir yoruma elverişli olmadığı, zorunlu ve emredici kuralların dar yorumlanmasının esas olduğu belirtilerek ticari nitelikteki menfi tespit davalarında dava açılmadan önce arabuluculuğa gidilmesinin zorunlu olmadığı yönde uyușmazlık giderilmiștir: "Bir ticari davanın açılmașından önce arabulucuya bașvurulmuş olmasının dava şartı olabilmesi bazı koşulların gerçekleșmesine bağlıdır. Buna göre; (a) Öncelikle konusu, bir miktar paranın ödenmesi olmal, (b) Sonra dava konusu olan bir miktar paranın ödenmesi için yapılan talep, bir alacak veya tazminat talebi olarak ileri sürülmelidir. Bu koşulların bulunması halinde dava açılmasından önce arabulucuya başvurulmuş olması, dava şartı olacaktır. Bu koşulların gerçekleşmediği ticari davalarda davanın açılmasından önce arabulucuya başvurulmuş olması, dava şartı olarak kabul edilmeyecektir. Kanun maddesinin metni ve gerekçesi bu kadar açık ve net olup zorlamayla da olsa genişletici bir yorum yapılmasına elverişli değildir. Zaten ileri ve özgürlükçü hukuk düzenlerinde zorunlu ve emredici kuralların dar yorumlanması esastır. Hal böyle olunca, yukarıda mahiyeti açılanan menfi tespit davalarının ticari bir dava olduğu için TTK'nun 5/A maddesi kapsamına alınması ve böyle bir davayı açmak isteyen kişinin önce arabulucuya başvurmaya zorlanması, kanuna aykırı olduğu gibi sayısız hukuki sakıncalara da neden olacaktır(...)Bu itibarla kanun hükmünde öngörülen açık ifadelere rağmen dava şartı arabuluculuğun uygulama alanının genişletilmesi doğru değildir. Böyle bir yaklaşım, özel bir dava şartı olan arabuluculuğa başvuru halini genel bir dava şartı haline getirecektir. HMK'nın 106. maddesinde düzenlenen tespit davasının özel bir şekli olan menfi tespit davası, konusu bir miktar paranın ödenmesi olan alacak ve tazminat davası olarak nitelendirilemez. Bu dava sonucunda, borçlunun borçlu olmadığının anlaşılması halinde borçlu olunmayan kısım belirtilmek suretiyle olumsuz tespit hükmü kurulmaktadır. Menfi tespit davasının istirdat davasına dönüştüğ̈̈ hâllerde dahi olumsuz tespit hükmü kurulması gerekmektedir. Başka bir deyişle, menfi tespit davasının niteliği gereği verilen kararlarda, yalnızca davacının borçlu olup olmadiğı belirlenmekte, borçlu olmadığ kısma ilişkin olumsuz tespit hükmü kurulmaktadır. Bu hüküm, herhangi bir alacağın tahsilini gerektirir nitelikte bir ilam olmadiğından esasa yönelik olarak İIK m. 32 uyarınca doğrudan ilamların icrası yolu ile takibe konulamaz. Oysa arabuluculuk sonucu verilen kararlar ilam hükmünde olup, cebri icra yoluna başvurulabilecek niteliktedir. Ancak yukarıda açıklandiğı gibi menfi tespit davaları sonucunda verilen hükümler esasa yönelik olarak cebri icraya konu edilip infaz edilemeyeceğinden, ticari davalarda arabuluculuğa başvuruyu dava şartı olarak öngören madde hükmünün amaçsal yorumundan Yasa Koyucu'nun bilinçli olarak menfi tespit davaların arabuluculuk dava şartına tabi tutmadiğı anlaşılmaktadır” Yargıtay 19. HD, E. 2020/85 K. 2020/454 T. 13.2.2020. (http://www.kazanci.com.tr/gunluk/19hd-2020-85.htm)

35 Ömer Ekmekçi/Muhammet Özekes/Murat Atalı/Vural Seven, Hukuk Uyuşmazlıklarında Arabuluculuk, 2. Baskı, Oniki Levha Yayınları, İstanbul 2019, s. 137 vd.; Muhammet Özekes, “Zorunlu Arabuluculuğun Hak Arama Özgürlüğü ve 
Buna karşılık bizim de katıldığımız ve hukukumuzda hakim görüş olan tek unsurlu teori doğrultusunda hareket ederek, dava konusu olarak münhasır olarak davacının mahkemeye yönelttiği talep sonucunu esas almak suretiyle TTK m. 5/A düzenlemesi ele alırsak, yalnızca dava dilekçesinde talep sonucu olarak bir miktar paranın ödenmesinin istenildiği alacak ve tazminat taleplerinin dava şartı arabuluculuk kapsamında kaldığı anlaşılacaktır. Para alacağı ya da tazminat talep edilen ticari davalarda kaynağın sözleşmeden, sebepsiz zenginleşmeden veya haksız fiilden doğmasının ise bir önemi yoktur ${ }^{36}$. Bu noktada TTK m. 5/A'da ifade edilen kapsama, yalnızca edaya - yani belli bir miktar paranın ödenmesine yönelik taleplerin gireceği, tespite yönelik taleplerin madde kapsamı dışında kaldığı belirtilmelidir ${ }^{37}$. Gerçekten de menfi ya da müspet tespit davalarıyla bir hukuki ilişkinin varlığının, yokluğunun ya da bir senedin sahteliğinin tespit edilmesi talep edilir. Bu dava türünde herhangi bir para alacağının ödenmesi istenmediği için, dava şartı arabuluculuk bu uyuşmazlıklar bakımından geçerli olmamalıdır. Maddeyle ilgili bu tafsilattan sonra aşağıda TTK m. 5/A kapsamındaki ticari alacaklar için yapılan ilamsız takiplerde açılan itirazın iptali davasında önce arabulucuya başvurma zorunluluğunun olup olmadığı Yargıtay 23. Hukuk Dairesi’nin gerekçeleriyle özel olarak incelenecektir.

\section{YARGITAY 23. HUKUK DAIRESI'NIN GEREKÇELERININ DEĞERLENDIRILMESi}

\section{ITIRAZIN IPTALI DAVASI BAKIMINDAN}

Yargıtay 23. Hukuk Dairesi'nin ticari uyuşmazlıklar için yapılan takipte açılan itirazın iptali davasının dava şartı arabuluculuğa tabi olduğu yönündeki gerekçeleri kanaatimizce birçok açıdan yerinde değildir. Öncelikle hangi ticari uyuşmazlıkların dava şartı arabuluculuğa tabi olduğunu belirlemede esas alacağımız TTK m. 5/A düzenlemesinde, yalnızca konusu bir miktar paranın ödenmesi olan alacak ve tazminat talepleri hakkında dava açılmadan önce arabulucuya başvurulmuş olmasını gerektiği ifade edilmiştir. Yargıtay 23. Hukuk Dairesi itirazın iptali davasını, borçlunun itirazın haksız olduğunun tespiti ve alacağın miktarının belirlenmesi suretiyle davacının alacağına kavuşmasını sağlayan, takip hukukuna özgü bir tahsil davası olarak nitelendirmiş ve tahsil amacına hizmet eden bu davanın dava şartı arabuluculuğa tabi olduğunu belirtmiştir. Kanaatimizce ticari uyuşmazlıklarda dava şartı arabuluculuğun sınırlarını belirlerken yapılan en önemli hatalardan biri, davanın bir miktar para alacağını ilgilendirmesi durumunda o davayı bir alacak-tahsil davası

Arabuluculuk İlkeleri Bakımından Değerlendirilmesi-Zorunlu Arabuluculuğa Eleştirel Bir Yaklaşım”, Arabuluculuğun Geliştirilmesi Uluslararası Sempozyumu, 2018, s. 126; Sibel Özel, "Zorunlu Arabuluculuğun Adalete Erişim Hakkı Çerçevesinde İrdelenmesi”, Public and Private International Law Bulletin, C. 40, S. 2, Y. 2020, s. 873; Atalı/Erdoğan, s. 217; Ermenek/Azaklı Arslan, s. 147-148.

36 Sinan Sarıkaya, "Yeniden Yapılandırma Davalarında (TTK m. 191-192-193) Arabuluculuk Üzerine Düşünceler", Legal Hukuk Dergisi, Y. 2019, C. 17, s. 3874.

37 Aynı yönde bkz: Ekmekçi/Özekes/Atalı/Seven, s. 190-191; Cafer Eminoğlu/Ersin Erdoğan, Ticari Uyuşmazlıklarda İhtiyari ve Dava Şartı (Zorunlu) Arabuluculuk, Ankara 2020, s. 221; Süha Tanrıver, Hukuk Uyuşmazlıkları Bağlamında Arabuluculuk, 2020, s. 140; Ertan Yardım, "Ticari Uyuşmazlıklarda Zorunlu Arabuluculuğa Başvuru”, Ticari Uyuşmazlıklarda Zorunlu Arabuluculuk (Editör: Ceyda Süral Efeçınar/Mehmet Ertan Yardım), Ankara 2019, s. 99-100; Ömer Faruk Demir, İstirdat Davası, Ankara 2020, s. 168; Paslı, s. 19; Atalı/Erdoğan, s. 216 vd; Özekes/Çiftçi, s. 122-123; Ermenek/Azaklı Arslan, s. 144-145. 
olarak niteleyerek dava şartı arabuluculuğa tabi tutma yönündeki eğilimdir. Oysa bir davanın belli bir paranın ödenmesi istemli açılması başka, davanın genel itibariyle tahsil amacına yönelmiş olması başka bir durumdur. Belli durumlarda yalnız bir tespit hükmü ya da inşai nitelikte bir hüküm de alacağın tahsilini amaçlayabilir, ama neticede belli bir miktar paranın ödenmesini konu alan bir eda hükmü ortaya çıkmayabilir. İIKK m. 68'de düzenlenen itirazın kaldırılması yolu bu noktada örnek gösterilebilir. İtirazın (kesin olarak) kaldırılması yargılamasında davacı haklı bulunduğunda alacaklı takibe devam ederek alacağına kavuşma yönünde icra prosedürlerini devam ettirebileceğinden bu dava tahsil amacına yönelir; ancak itirazın kesin kaldırılması kararı belli bir miktar paranın ödenmesini emreden bir eda hükmü değildir.

Karara konu olan itirazın iptali davasını ele aldığımızda kanaatimizce davanın hukuki niteliğiyle ilgili doktrindeki bir grup yazar tarafından ileri sürülen “icra iflas hukukuna özgü bir tahsil davası” tanımı yerindedir ve bu tanım Yargıtay 23. Hukuk Dairesi tarafından, itirazın iptali davasının TTK m. 5/A kapsamında değerlendirilmesi gerektiği yönünde bir gerekçe olarak kullanılmıştır. Bu tanımdan ne anlaşılması gerektiğini daha net belirlemek için itirazın iptali davasının ne tür sonuçlar doğurduğuna detaylı bakmak gerekir.

Davaların hukuki niteliğini (ve aynı zamanda dava konusunu) belirleyen temel unsur davacının talebidir. Bu noktada itirazın iptali davasını ele aldığımızda kanaatimizce davacının esas talebi iki noktaya yönelmektedir: takibi durduran itirazın iptal edilmesi ve davacının takip konusu alacağın alacaklısı olduğunun belirlenmesi ${ }^{38}$. Davacının genel hükümlere göre görülen yargılamanın sonunda haklı çıkması durumunda mahkeme hem itirazın iptaline hem de alacaklının alacağının mevcudiyetine karar verecektir. Alacaklının davayı kazanması üzerine itirazın iptal edilmesi inşai nitelik taşır ${ }^{39}$. Zira borçlunun itirazının hükümsüz kılınmasıyla birlikte duran takip alacaklının talebi üzerine ilerlemeye devam edecek ve alacaklı takibin ilerleyen aşamalarına geçerek icra prosedürü dahilinde alacağını elde etmeye yaklaşacaktır. Mevcut takip hukuku ilişkisini değiştiren itirazın iptali kararı, bu yönüyle bozucu nitelikte usuli bir inşai karar olarak değerlendirilebilir. İtirazın bertaraf edilmesinin yanında mahkeme yapmış olduğu muhakeme neticesinde alacaklının haklı olduğunu görürse, alacaklının takibe konu ettiği meblağın gerçekten alacaklısı olduğu yönünde bir tespit kararı verecektir. Bu noktada kanaatimizce itirazın iptali kararında ayrıca alacağın tahsiline de hükmedileceği ve bu hükmün alacağın ödenmesini emreden bir eda hükmü olduğundan bahsedilmesi yerinde değildir. Çünkü eğer itirazın iptali davası sonucunda verilen hükmü bir eda hükmü olarak nitelendirirsek alacaklının o kararla birlikte ilamlı icraya da başvurabileceğini söylemek gerekir. Oysa halihazırda devam eden takipte haciz istenebilecekken alacaklının yeni harçlar ödeyerek icra dairesine başvurması ve borçluya bir icra emrinin gönderilmesini sağlayarak ancak onun üzerine haciz aşamasına gelebilmesinde hukuki yararı yoktur ${ }^{40}$.

38 Davacı ve davalı itirazın iptali davasında kendi lehlerine icra tazminatına hükmedilmesini de isteyebilirler (İİK m. 67/2). İcra tazminatıyla ilgili değerlendirme ileride ayrıca yapılacaktır.

39 Benzer yönde: Ermenek/Azaklı Arslan, s. 156.

40 Yilmaz, İtirazın Íptali, s. 612. 
Yargıtay 23. Hukuk Dairesi tarafından itirazın iptali davasının açılması halinde aynı alacakla ilgili genel hükümlere göre alacak davası açılmasında hukuki yarar olmadı̆̆ı, bu davanın bir tahsil davası olduğu yönünde ileri sürülen gerekçelerdendir. Anlaşıldığı üzere Yargıtay takip konusu alacak için açılan bir alacak davası ile aynı alacak için yapılan takipte açılan itirazın iptali davasını birbirine denk davalar olarak değerlendirmekte ve bu yönden itirazın iptali davasının alelade bir alacak davasının hükümlerine tabi olması gerektiğini savunmaktadır. Gerçekten de alacaklının başlattığı bir icra takibi itiraz üzerine durmuşken bu itirazın giderilmesi için süresi içerisinde bir itirazın iptali davası açması yerine yeniden bir alacak davası açmasında hukuki yarar yoktur. Zira itirazın iptali davasının alacaklı lehine sonuçlanması durumunda hem takibe devam edilmekte hem de alacağın varlığı kesin olarak tespit edilmektedir. Fakat bu husus aynı zamanda ele alınan iki davanın farklılığını da gösterir. Zira itirazın iptali davası her ne kadar alacağın varlığını genel hükümler çerçevesinde belirlese de bu dava asıl sonuçlarını alakalı olduğu takip bakımından doğurur. Alacaklı, lehine olan itirazın iptali kararıyla, icra dairesinden haciz aşamasına geçilmesini isteyebilir. Oysa ayrı bir alacak davası sonucunda verilen hüküm alacaklının lehine olsa bile, talebin yerine getirilmesi için yeni bir takibe başvurulması gerekir. Dolayısıyla itirazın iptali davası asli sonuçlarını usul hukukunda doğururken klasik bir alacak davası maddi hukuk temelinde etkiler doğurur. Keza hukukumuza özel bir yaptırım olan icra inkâr tazminatı da ancak itirazın iptali davasıyla talep edilebilirken normal bir alacak davası böyle bir hak tanımaz. Bu sebeple amaç ve fonksiyon yönünden ayrışan bu iki davaya birebir aynı dava gibi muamele edilmemesi, biri üzerinden diğeri için hukuki nitelendirme yapılmaması gerektiği kanaatindeyiz.

Bahsettiğimiz gerekçelerle kanaatimizce itirazın iptali davası genel çerçevede alacağın takip yoluyla tahsil edilmesine yönelmiş bir dava olmakla birlikte, neticede alacağın tahsil edilmesine hükmedilen klasik bir eda davası değildir. Bilakis bu davanın kabulüyle hem inşai hem de tespit edici nitelik taşıyan karma bir hüküm ortaya çıkar. Alacağın tahsili ise itirazın iptali üzerine takibin ilerlemesi ve haczedilen malların paraya çevrilmesiyle sağlanır. Görüldüğü üzere maddi hukuk bakımından sonuçlar doğursa da bu dava takibi ilerletmeyi ve alacağın başlatılan takip dahilinde elde edilmesini sağlayan bir takip hukuku davasıdır ve temel etkilerini takip hukukunda doğurur. İtirazın iptali kararı icraya uygun olmadığı gibi kararın icraya koyulmasında hukuki yarar da bulunmaz. İtirazın iptaliyle birlikte TTK m. 5/A’da ifade edildiği üzere bir miktar paranın ödenmesini konu eden bir karar ortaya çıkmadığı için bu davanın dava şartı arabuluculuğa tabi olmadığı kanaatindeyiz ${ }^{41}$. Esasen Yargıtay 23. Hukuk Dairesi de bu dava sonucunda bir eda hükmü ortaya çıkacağından ya da davalının takip konusu alacağı ödemeye mahkûm edileceğinden bahsetmemiştir. Aksine itirazın iptali davasının "itirazın haksız olduğunun tespiti ve alacağın miktarının belirlenmesi” fonksiyonunu ifa ettiğini belirterek aslında mahkemenin bir tespit faaliyetinde bulunduğunu ifade etmiştir. Buna rağmen

41 Bu yönde görüşü savunanlar için bkz: Ekmekçi/Özekes/Atalı/Seven, s. 197; Pekcanıtez/Sungurtekin Özkan/Atalay/ Özekes, s. 111; Tanrıver, Arabuluculuk, s. 139; Tanrıver, Dava Şartı, s. 123; Yardım, s. 103; Nihat Taşdelen, Ticari Uyuşmazlıkların Çözümünde Alternatif Bir Çözüm Yolu Olarak Arabuluculuk, Ankara 2021, s. 97-98; Ermenek/Arslanlı, s. 160. İtirazın iptali davasının zorunlu arabuluculuğa tabi olması gerektiği yönde bkz: (TTK m. 5/A'da davadaki talep sonucu değil de dava sebebinin dikkate alınması gerektiğini savunan, bu sebeple itirazın iptali davasında arabuluculuğa başvurulmasını zorunlu olduğunu ileri süren) Ali Cem Budak/Varol Karaarslan, Medeni Usul Hukuku, 4. Baskı, Adalet Yayınevi, Ankara 2020, s. 480; Mahmut Coşkun, İtirazın İptali - Menfi Tespit ve İstirdat - Tasarrufun İptali - İflas ve İflasın Ertelenmesi - Sıra Cetveline İtiraz Davaları, 7. Baskı, 2021, s. 87; Koçyiğit/Bulur, s. 67; Kurt Konca, s. 5; Paslı, s. 22. 
Yargıtay 23. Hukuk Dairesi davanın alacağın tahsilini sağlama amacına hizmet ettiğine vurgu yapmış ve bu amacı geniş yorumlamak suretiyle dava sonucunda esasen belli bir miktar paranın ödenmesine hükmedilmemesine rağmen, davanın TT m. 5/A kapsamına girdiği yönde karar vermiştir.

\section{ICRA TAZMINATI BAKIMINDAN}

Yargıtay 23. Hukuk Dairesi'nin kararı, itirazın iptali davasında talep üzerine hükmedilen icra tazminatı $^{42}$ yönünden de ele alınmalıdır. İİK m. 67/2'ye göre bu davada borçlunun itirazının haksızlığına karar verilirse borçlu, takibinde haksız ve kötü niyetli görülürse alacaklı, diğer tarafın talebi üzerine iki tarafın durumuna, davanın ve hükmolunan şeyin tahammülüne göre red veya hükmolunan meblağın yüzde yirmisinden aşağı olmamak üzere uygun bir tazminata mahkûm edilir. İcra tazminatıyla belli bir miktar paranın ödenmesi talep edildiği için lafzi olarak değerlendirildiğinde ilk bakışta bu tazminatın TTK m. 5/A’da öngörüldüğü üzere "konusu bir miktar paranın ödenmesi olan alacak ve tazminat talepleri” kapsamına girdiği varsayılabilir. Bu varsayımın geçerli olup olmadığını anlayabilmek için ilk olarak icra inkar tazminatının hukuki niteliğini ele almak gerekir.

Nispeten daha eski bir dönemde savunulan bir görüşe göre icra inkar tazminatı borçlar hukuku anlamında bir tazminattır. Dolayısıyla eğer borçlu tarafından takibe yapılan itirazla takibin durması üzerine alacaklı bir zarara uğramamışsa, alacaklı lehine bir tazminata hükmedilmeyecektir ${ }^{43}$. Buna karşılık bizim de katıldığımız bugünkü hakim görüşe göre ise icra tazminatı borçlar hukuku anlamında bir tazminat türü değildir. Bilakis cebri icra hukukuna özgü, şartları ve hükümleri icra kanunumuzda düzenlenen cezai nitelikte bir yaptırımdır ${ }^{44}$. İIKK m. 67/2'de düzenlenen icra inkâr tazminatı, yalnızca itirazın iptali davasıyla birlikte talep edilebildiği için itirazın iptali davası dışında herhangi bir yolla istenmesi ve bu tazminata hükmedilmesi mümkün değildir ${ }^{45}$. Hatta bu sebeple tahkimde görülen itirazın iptali davasında icra inkar tazminatına hükmedilemeyeceği, uyuşmazlığı maddi hukuk

42 İcra ve İflas Kanunu’nun çeşitli maddelerinde takibin hızlandırılması veya kötü niyetle takip yapılmasının önlenmesi amacıyla tarafların ya da ilgililerin haksız ya da kötü niyetli olarak hareket ettiklerinin kabul edildiği bazı durumlarda belli bir miktar icra tazminatına mahkûm edileceği düzenlenmiştir. İtirazın iptali davasında borçlunun ödeme emrine haksız olarak itiraz etmesi halinde ödeyeceğinin öngörüldüğü tazminat, borçlunun takibe konu borcu inkâr etmesi sebebiyle 'icra inkâr tazminatı' olarak isimlendirilirken, alacaklı aleyhine icra tazminatına hükmedilebilmesi için kanunda kötüniyet şartı aranması sebebiyle bu tazminat da doktrinde 'kötü niyet tazminatı' olarak isimlendirilmektedir. Bkz: Ejder Yllmaz, "İcra Tazminatı", Haluk Konuralp Anısına Armağan, C. II, Ankara 2009, s. 680; Ayşe Kılınç, "İcra Tazminatına Hükmedilebilmesinde Talep Koşulu ve Taleple Bağlılık İlkesi Bakımından Değerlendirilmesi”, DEÜHFD, C. XXI, S. 1, 2019, s. 212. Çalışmamızda her iki taraf lehine de hükmedilecek tazminatı kapsayacak şekilde değerlendirme yapılacağı için, icra tazminatı ifadesi tercih edilmiştir.

43 Mustafa Reşit Belgesay, İcra ve İflâs Kanunu Șerhi, C. I, İstanbul 1955, s. 137.

44 Yılmaz, İcra Tazminatı, s. 684; Baki Kuru, "İcra İnkar Tazminatı", Yargıtay Yüzüncü Yıldönümü Armağanı, İstanbul 1968, s. 727-728; Deynekli/Kısa, s. 217; Kılınç, s. 214-215; Gülcan Sunar, İcra Hukukunda İcra Tazminatı, Marmara Üniversitesi Sosyal Bilimler Enstitüsü, Yayınlanmamış Yüksek Lisans Tezi, İstanbul 1995, s. 14; Cemre Tüysüz, Milletlerarası Ticari Tahkim Açısından İcra ve İflas Hukukundaki Davalar, İstanbul 2017, s. 114; Cenk Akil, "İtirazın İptali Davasında İcra İnkar Tazminatının Şartı Olarak Borçlunun İtirazının Haksızlığına Karar Verilmesi”, İnönü Üniversitesi Hukuk Fakültesi Dergisi, C. 3, S. 1, Y. 2012, s. 321.

45 Baki Kuru, İcra ve İflas Hukuku El Kitabı, 2. Baskı, Adalet Yayınevi, Ankara 2013, s. 263; Yılmaz, İcra Tazminatı, s. 696; Pekcanıtez/Sungurtekin Özkan/Atalay/Özekes, s. 114; Hakan Pekcanıtez, "Tahkimde Açılan İtirazın İptali Davasında Hakemler İcra ve İnkâr Tazminatına Karar Verilebilir mi?”, Fasikül Hukuk Dergisi, C. 10, S. 100, Y. 2018, s. 63; Ermenek/ Arslanl, s. 173. 
boyutuyla çözecek olan hakemlerin icra inkar tazminatına karar vermekle yetkili olmadıkları kabul edilmektedir ${ }^{46}$. Bu doğrultuda her ne kadar icra inkâr tazminatılla belli bir miktar para ödenmesi talep edilse de bu tazminatın cebri icra alanına münhasır olması ve takip hukukundaki davalardan ayrı serdedilememesi sebebiyle dava şartı arabuluculuk kapsamında kalmadığı söylenmelidir ${ }^{47}$. Doğaldır ki itirazın iptali davasında öncelikle arabulucuya gitmesi ve borçlunun haksız olarak takibe itiraz etmiş olması faraziyesinde taraflar anlaşarak alacaklının alacağına geç kavuşmasından kaynaklanan zararının giderilmesini kararlaştırabilirler. Ancak bunun için tarafların anlaşması gereklidir ve bu halde kararlaştırılacak kalem icra inkâr tazminatı değil, olsa olsa müspet zararın giderilmesi olur. Oysa aynı talebin itirazın iptali davası içinde ileri sürülmesi durumunda alacaklının alacağının ve borçlunun haksızlığının tespit edilmesiyle, alacaklının talebi üzerine karşı tarafın rızası olmasa bile icra inkâr tazminatına hükmedilmektedir. Bu değerlendirmeler ışı̆̆ında denilebilir ki itirazın iptali davasının dava şartı arabuluculuğa tabi tutulması, tarafların elinden icra inkâr tazminatı hakkının alınması sonucunu da doğurabilir. Oysa ki icra inkâr tazminatı takibin gereksiz yere sürüncemede bırakılmasına ya da kötü niyetli olarak takip yapılmasına yönelik davranışları caydırmak, aksi hareketi de cezalandırmak amacıyla getirilen ve kendi hukuk sistemimize mahsus önemli bir yaptırım türüdür. Yargıtay 23. Hukuk Dairesi’nin kararı bu yönüyle cebri icra hukukuna özgü yaptırım araçlarının işlevsiz kalmasına sebebiyet verebilecektir.

Son olarak belirtmek gerekir ki itirazın iptali davasından önce tüketilmesi gereken arabuluculuk yolu, ilamsız icranın alacağa hızlı ve pratik bir şekilde ulaşılmasını sağlama özelliğini de zedelemektedir. İtirazın iptali davasının zorunlu arabuluculuğa tabi tutulmasıyla birlikte alacaklının takiple getirilen prosedürlere maruz kalmak yerine doğrudan dava açmayı tercih etmesi, bu doğrultuda ilamsız icranın etkinliğinin azalması muhtemel bir sonuçtur.

\section{SONUÇ}

Karar incelemesi neticesinde varılan sonuçlar aşağıdaki gibi özetlenebilir:

Yargıtay 23. Hukuk Dairesi, bölge adliye mahkemeleri hukuk daireleri arasındaki görüş farklılıklarını gidermek için toplanmış ve iş bölümü alanına giren Sakarya Bölge Adliye Mahkemesi 7. Hukuk Dairesi ile ile Ankara Bölge Adliye Mahkemesi 23. Hukuk Dairesi’nin TTK m. 5/A kapsamında kalan talepler için açılan itirazın iptali davasında zorunlu olarak önce arabuluculuya başvurulacağını, bölge adliye mahkemeleri daireleri arasında görüş farklılıklarının nasıl giderileceğini düzenleyen 5235 sayılı Kanun m. 35/2’e göre kesin olarak karara bağlamıştır. Görüş ayrılıklarını gidermekle görevli Yargıtay Dairesi yalnızca kendi iş bölümüne giren bölge adliye mahkemesi kararları bakımından değerlendirme yapmakta ve kendi iş bölümüne girmeyen diğer bölge adliye mahkemesi kararlarını, farklı görüş bildiren kararlar ortaya koysalar dahi incelememektedir. Kanaatimizce olması gereken hukuk bakımından bölge adliye mahkemeleri daireleri arasındaki görüş farklılıkları, 2017 yılında

46 Pekcanıtez, s. 63-64; Atalı/Ermenek/Erdoğan, s. 151; Tüysüz, s. 116; Cenk Akil/Mehmet Akif Gül: "Yargitay’ın Genel Haciz Yoluyla İlâmsız Takibe Başvuru Hakkına İlişkin Olarak Vermiş Olduğu Bazı Kararlar Üzerine Düşünceler”, Yargıtay Dergisi, C. 43, S. 3, Y. 2017, s. 568.

47 Bu yönde bkz: Ekmekçi/Özekes/Atalı/Seven, s. 197; Ermenek/Arslanlı, s. 173-174. 
696 sayılı OHAL KHK’sılla Yargıtay Kanunu m. 15’te yapılan değişiklikten önce öngörüldüğü gibi içtihadı birleştirme yoluyla giderilmelidir. Amaç hukukun yeknesak uygulanması ise, diğer dairelerin kararlarının ve gerekçelerinin de görüş aykırılıklarının giderileceği nihai kararın oluşturulması aşamasında ele alınması gereklidir. Yine 5235 sayılı Kanun m. 35/2'de, ilgili Yargıtay Dairesi’nin uyuşmazlığın giderilmesine ilişkin vereceği kararın kesin olduğu belirtilmekte; ancak bu kararın değerlendirilmeye alınmayan diğer bölge adliye mahkemeleri ya da alt derece mahkemeleri bakımından bağlayıcı olduğuyla ilgili herhangi bir ifade bulunmamaktadır. Bu gerekçelerle bölge adliye mahkemesi daireleri arasındaki içtihat farklılıklarının hem görüş ayrılığını gideren kararın diğer mahkemeler bakımından bağlayıcılığının açık olması hem de görüş ayrılı̆̆ının giderilmesi aşamasında iş bölümü ayrımı yapılmaksızın değerlendirme yapılması sebebiyle hukukumuzda uzun yıllardır uygulaması olan içtihadı birleştirme yoluyla giderilmesinin daha uygun olacağı kanaatindeyiz.

Yargıtay 23. Hukuk Dairesi itirazın iptali davasını takip hukukuna özgü bir tahsil davası olarak nitelendirip dava açılmadan önce TTK m. 5/A kapsamında dava şartı arabuluculuğa tabi olduğuna karar vermiştir. TTK m. 5/A'da yalnızca ticari davalardan konusu bir miktar paranın ödenmesi olan alacak ve tazminat talepleri hakkında dava açılmadan önce arabulucuya başvurulmuş olması dava şartı olarak düzenlenmiştir. Oysa itirazın iptali davasının alacağın tahsiline yönelen bir dava olması, belli bir miktar paranın ödenmesini konu eden alacak veya tazminat davası olduğu anlamına gelmez. İtirazın iptali davasıyla takip konusu paranın tahsil edilmesi değil, alacaklının alacağının tespit edilmesi ve bu doğrultuda takibi durduran itirazın iptal edilmesi amaçlanır. İtirazın iptali hükmün inşai kısmını oluştururken, alacaklı olunan miktarın belirlenmesi ise hükmün tespit bölümünü oluşturur. Bu dava sonucunda alacaklının alacağının olup olmadığı ya da ne kadar olduğu kesin hükümle belirlense de asıl olarak duran takibe devam edilerek alacağın başlatılan takip içerisinde elde edilmesi sağlanır. Dolayısıyla itirazın iptali davası sonucunda takip konusu alacağın tahsiline yönelik bir eda hükmü elde edilmez; bilakis bu kararla hali hazırda başlamış bulunan takibin ilerlemesi sağlanır. Bu sebeple Yargıtay 23. Hukuk Dairesi’nin aksine, itirazın iptali davasının TTK m. 5/A anlamında dava şartı arabuluculuğa tabi davalardan olmadığı kanaatindeyiz.

İtirazın iptali davasında talep üzerine hükmedilecek icra inkâr tazminatlarının da arabuluculuğa elverişli kalemlerden olmadığı kanaatindeyiz. Zira icra inkâr tazminatı borçlar hukuku anlamında bir tazminat değil, itirazın iptali davasına bağlı ve cebri icra sistemine özgü bir cezai yaptırımdır. Arabulucu münhasıran cebri icra sürecindeki davalara özgü bir yaptırıma karar veremeyecektir. Ticari dava niteliğindeki itirazın iptali davasınında zorunlu olarak arabuluculuğa başvurulması, tarafların davada hak kazanabilecekleri icra inkâr tazminatından arabuluculuk sürecinde yoksun kalabilmeleri ihtimali sebebiyle de dezavantajlı bir karardır.

Son olarak tarafların alacaklarına daha seri, herhangi bir ek prosedüre ve belgeye gerek duyulmaksızın kavuşabilecekleri ilamsız icra sistemindeki davaların dava şartı arabuluculuğa tabi tutulmasının, bu takipten beklenebilecek menfaatleri önemli ölçüde azaltabileceğini düşünüyor ve Yargıtay 23. Hukuk Dairesi kararını bu yönüyle de takip ekonomisine aykırı buluyoruz. 


\section{KAYNAKÇA}

Akil, Cenk: “İtirazın İptali Davasında İcra İnkar Tazminatının Şartı Olarak Borçlunun İtirazının Haksızlığına Karar Verilmesi”, İnönü Üniversitesi Hukuk Fakültesi Dergisi, C. 3, S. 1, Y. 2012.

Akil,Cenk/Gül, Mehmet Akif: "Yargıtay’ın Genel Haciz Yoluyla İlâmsız Takibe Başvuru Hakkına İlişkin Olarak Vermiş Olduğu Bazı Kararlar Üzerine Düşünceler”, Yargıtay Dergisi, C. 43, S. 3, Y. 2017.

Alangoya/M. Kamil Yıldırım/Nevhis Deren Yıldırım, Medeni Usul Hukuku Esasları, 7. Baskı, Beta Basım Yayımı

Arslan, Ramazan/Yılmaz, Ejder/Taşpınar Ayvaz, Sema/Hanağası, Emel: İcra ve İflas Hukuku, 5. Baskı, Yetkin Yayınları, Ankara 2019.

Atalı, Murat: Pekcanıtez Usul, C. III, 15. Bask1, İstanbul 2017.

Atalı, Murat/Ermenek, İbrahim/Erdoğan, Ersin: İcra ve İflas Hukuku, 3. Baskı, Yetkin Yayınları, Ankara 2020.

Atalı, Murat/ Erdoğan, Ersin: “Türk Ticaret Kanunu’nun 5/A Maddesi Çerçevesinde Menfi Tespit Davaları Sorunu”, Çankaya Üniversitesi Hukuk Fakültesi Dergisi, Y. 2020, C. 5, S. 1.

Belgesay, Mustafa Reşit: İcra ve İflâs Kanunu Şerhi, C. I, İstanbul 1955.

Berkin, Necmettin: Tatbikatçılar İçin İcra Hukuku Rehberi, İstanbul 1980.

Börü, Levent: Dava Konusunun Devri, Yetkin Yayınları, Ankara 2012.

Börü, Levent/ Koçyiğit, İlker: Ticari Dava, 2. Baskı, Ankara 2021.

Budak, Ali Cem: “Ticari Davalarda Dava Şartı Olarak Arabuluculuk”, MİHDER, Y. 2019, C. 15, S. 42.

Budak, Ali Cem/Karaarslan,Varol: Medeni Usul Hukuku, 4. Baskı, Adalet Yayınevi, Ankara 2020.

Coşkun, Mahmut: İtirazın İptali - Menfi Tespit ve İstirdat - Tasarrufun İptali - İflas ve İflasın Ertelenmesi - Sira Cetveline İtiraz Davaları, 7. Baskı, 2021.

Çağa, Tahir: “Ödeme Emrine İtirazın İptali Davasına Dair”, BATİDER, Ankara 1976, C. VIII, S. 3.

Demir, Ömer Faruk: İstirdat Davası, Ankara 2020.

Deynekli, Adnan/Kısa, Sedat: İtirazın İptali Davaları, Turhan Kitabevi, Ankara 2013.

Ekmekçi, Ömer/Özekes, Muhammet/Atalı, Murat/ Seven, Vural: Hukuk Uyuşmazlıklarında Arabuluculuk, 2. Baskı, Oniki Levha Yayınları, İstanbul 2019.

Eriş, Gönen: “Ödeme Emrine İtirazın İptali Davası ve Bazı Sorunlar”, ABD, Y. 1977, S. 5.

Erdem, Murat: İcra ve İflas Hukukunda İtirazm İptali Davası, Ankara Üniversitesi Sosyal Bilimler Enstitüsü, Yayınlanmamış Doktora Tezi, Ankara 2010.

Ermenek, İbrahim/Azaklı Arslan, Betül: "İcra ve İflâs Hukuku Açısından Ticarî Davalarda Arabulucuya Başvuru Zorunluluğu (TTK m. 5/A)”, TBBD, Y. 2020, S. 148.

Eminoğlu, Cafer/Erdoğan, Ersin: Ticari Uyuşmazlıklarda İhtiyari ve Dava Şartı (Zorunlu) Arabuluculuk, Ankara 2020.

Özkaya-Ferendeci, Hamide Özden: Kesin Hükmün Objektif Sinırları, İstanbul 2009.

Gürdoğan, Burhan: İcra Hukuku Dersleri, Ajans Türk Matbaası, Ankara 1970.

Hanağası, Emel: Davada Menfaat, Yetkin Yayınları, Ankara 2009.

Karsl1, Abdurrahim: İcra ve İflas Hukuku, 3. Baskı, Alternatif Yayınevi, İstanbul 2014.

Kılınç, Ayşe: "İcra Tazminatına Hükmedilebilmesinde Talep Koşulu ve Taleple Bağlılık İlkesi Bakımından Değerlendirilmesi”, DEÜHFD, C. XXI, S. 1, İzmir 2019.

Koçyiğit, İlker/Bulur, Alper: Ticari Uyuşmazlıklarda Dava Şartı Arabuluculuk, Ankara 2019.

Kren Kostkiewicz, Jolanta /Vock, Dominik: Kommentar zum Bundesgesetz über Schuldbetreibung und Konkurs SchKG, 4. Auflage, 2017. 
Kurt Konca, Nesibe: “Ticari Uyuşmazlıklarda Dava Şartı (Zorunlu) Arabuluculuk”, SETA Perspektif, Y. 2018, S. 225.

Kuru, Baki: İcra ve İflas Hukuku, C. I, 3. Baskı, Evrim Dağıtım, İstanbul 1988.

Kuru, Baki: İcra ve İflas Hukuku El Kitabı, 2. Baskı, Adalet Yayınevi, Ankara 2013.

Kuru, Baki: “İcra İnkar Tazminatı”, Yargıtay Yüzüncü Yıldönümü Armağanı, İstanbul 1968.

Muşul, Timuçin: İcra ve İflas Hukuku, C. I, Adalet Yayınevi, 5. Baskı, Ankara 2013.

Muşul, Timuçin: Medeni Yargılama Hukukunda Terdit İlişkileri, 2. Basım, Ankara 2009.

Okçuoğlu, Yavuz: “İcra Hukukunda İtirazın İptali ve İnkâr Tazminatı”, Bursa Barosu Dergisi, S. 1980/11.

Önen, Ergun: İsşai Dava, Olgaç Matbaası, Ankara 1981.

Özekes, Muhammet: "İstinaf Sistemiyle Birlikte Hukuk Yargılamasında İçtihat Ayrılıklarının Giderilmesi”, Türkiye'de İstinaf Mahkemelerinin Kurulmasindan Sonra Yargitay’ın Rolü Konferansı, Ankara, 2007.

Özekes, Muhammet: “Zorunlu Arabuluculuğun Hak Arama Özgürlüğü ve Arabuluculuk İlkeleri Bakımından

Değerlendirilmesi-Zorunlu Arabuluculuğa Eleştirel Bir Yaklaşım”, Arabuluculuğun Geliştirilmesi Uluslararası Sempozyumu, 2018.

Özekes, Muhammet/Çiftçi, Pınar: "Menfî Tespit Davalarını Zorunlu Arabuluculuğa Dahil Saymanın Gereksizliği Üzerine”, TBBD, C. 33, S. 148, Y. 2020.

Özel, Sibel: "Zorunlu Arabuluculuğun Adalete Erişim Hakkı Çerçevesinde İrdelenmesi”, Public and Private International Law Bulletin, C. 40, S. 2, Y. 2020.

Pasl, Ali: “Ticari İşletme ve Ticaret Şirketleri Bakımından Zorunlu Arabuluculuğun Değerlendirilmesi: Türk Ticaret Kanunu 5/A maddesinin yorumlanması," Ticari Uyuşmazlıklarda Zorunlu Arabuluculuk, Editör: Ceyda Süral, Mehmet Ertan Yardım, Seçkin Yayıncılık, Ankara 2019.

Pekcanıtez, Hakan: "Tahkimde Açılan İtirazın İptali Davasında Hakemler İcra ve İnkâr Tazminatına Karar Verilebilir mi?”, Fasikül Hukuk Dergisi, C. 10, S. 100, Y. 2018.

Pekcanıtez, Hakan/Atalay, Oğuz/Sungurtekin Özkan, Meral/Özekes, Muhammet: İcra ve İflas Hukuku Ders Kitabı, 6. Baskı, Oniki Levha Yayınları, 2020.

Postacıoğlu, İlhan E.: İcra Hukuku Esasları, İstanbul Üniversitesi Yayınları, İstanbul 1969.

Postacıoğlu, İlhan E. /Altay, Sümer: İcra Hukuku Esasları, 5. Bası, 2010.

Postacıoğlu, İlhan E.: Medeni Usul Hukuku Dersleri, 6. Baskı, İstanbul 1975.

Sarıkaya, Sinan: "Yeniden Yapılandırma Davalarında (TTK m. 191-192-193) Arabuluculuk Üzerine Düşünceler”, Legal Hukuk Dergisi, Y. 2019, C. 17.

Sunar, Gülcan: İcra Hukukunda İcra Tazminatı, Marmara Üniversitesi Sosyal Bilimler Enstitüsü, Yayınlanmamış Yüksek Lisans Tezi, İstanbul 1995.

Tanrıver, Süha: “Dava Şartı Arabuluculuk Üzerine Bazı Düşünceler”, TBBD, Y. 2020, S. 147 (Dava Şartı).

Uyar, Talih: İcra Hukukunda İtiraz, 2. Bası, Manisa 1990.

Tanrıver, Süha: Hukuk Uyuşmazlıkları Bağlamında Arabuluculuk, 2020 (Arabuluculuk).

Tanrıver, Süha: “Dava Şartı Arabuluculuk Üzerine Bazı Düşünceler”, TBBD, Y. 2020, S. 147 (Dava Şartı).

Tanrıver, Süha: Medeni Usul Hukuku, C. I, 2. Baskı, Ankara 2018 (Usul).

Tanrıver, Süha: Medeni Usul Hukukunda Derdestlik İtirazı, Ankara Üniversitesi Hukuk Fakültesi Yayınları, Ankara 1998.

Tanrıver, Süha: Hukuk Uyuşmazlıkları Bağlamında Arabuluculuk, 2020.

Taşdelen, Nihat: Ticari Uyuşmazlıkların Çözümünde Alternatif Bir Çözüm Yolu Olarak Arabuluculuk, Ankara 2021.

Türkiye Barolar Birliği, Ticari Uyuşmazlıklarda Dava Şartı Olan Arabuluculukta Taraf Vekilliği El Kitabı, 2019. 
Tüysüz, Cemre: Milletlerarası Ticari Tahkim Açısından İcra ve İflas Hukukundaki Davalar, Beta Yayınevi, İstanbul 2017.

Üstündağ, Saim: İddia ve Müdafaanın Değisştirilme Yasağı, 1967.

Vock, Dominik /Meister-Müller, Danièle: SchKG-Klagen nach der Schweizerischen ZPO, 2. Auflage, 2018.

Yardım/Ertan Mehmet: “Ticari Uyuşmazlıklarda Zorunlu Arabuluculuğa Başvuru”, Ticari Uyuşmazlıklarda Zorunlu Arabuluculuk, Editör: Ceyda Süral, Mehmet Ertan Yardım, Seçkin Yayıncılık, Ankara 2019.

Yazıcı Tıktık, Çiğdem: “Ticari Davalarda Dava Şartı Olarak Arabuluculuk Uygulamasının Temel İlkeler Bakımından Değerlendirilmesi”, Ticari Uyuşmazlıklarda Zorunlu Arabuluculuk (Editör: Ceyda Süral Efeçınar/Mehmet Ertan Yardım), Ankara 2019.

Yıldırım, Kâmil/Yıldırım, Nevhis Deren, İcra ve İflas Hukuku, 6. Baskı, Beta Yayınları, İstanbul 2015.

Yllmaz, Ejder: Medeni Yargılama Hukukunda Islah, 5. Baskı, Ankara 2021, (Islah).

Yılmaz, Ejder: “İtirazın İptali Davasının Hukuki Niteliği”, Prof. Dr. Saim Üstündă̆ Armăganı, Adalet Yayınevi, Ankara 2009 (İtirazın İptali).

Yılmaz, Ejder: “İcra Tazminatı”, Haluk Konuralp Anısına Armağan, C. II, Ankara 2009 (İcra Tazminatı)

Yılmaz, Ejder: “İçtihadı Birleştirme” veya “Adaletteki Çelişkiye Son Verme” İhtiyacı”, Ticaret Hukuku ve Yargıtay Kararları Sempozyumu XVIII, Banka ve Ticaret Hukuku Araşturması Enstitüsü, 2010.

\section{KISALTMA CETVELI}

$\begin{array}{ll}\text { ABD } & : \text { Ankara Barosu Dergisi } \\ \text { BATİDE } & : \text { Banka ve Ticaret Hukuku Dergisi } \\ \text { Bkz } & : \text { Bakınız } \\ \text { C } & : \text { Cilt } \\ \text { DEÜHFD } & : \text { Dokuz Eylül Üniversitesi Hukuk Fakültesi Dergisi } \\ \text { HD } & : \text { Hukuk Dairesi } \\ \text { HMK } & : \text { Hukuk Muhakemeleri Kanunu } \\ \text { HUMK } & : \text { Hukuk Usulü Muhakemeleri Kanunu } \\ \text { İIK } & : \text { İcra ve İflas Kanunu } \\ \text { KHK } & : \text { Kanun Hükmünde Kararname } \\ \text { m. } & : \text { Madde } \\ \text { MİHDER } & : \text { Medeni Usul ve İcra İflas Hukukçuları Dergisi } \\ \text { OHAL } & : \text { Olağanüstü hal } \\ \text { S } & : \text { Sayı } \\ \text { SchKG } & : \text { Bundesgesetz über Schuldbetreibung und Konkurs } \\ \text { TBBD } & : \text { T ürkiye Barolar Birliği Dergisi } \\ \text { TTK } & : \text { Türk Ticaret Kanunu } \\ \text { vd. } & : \text { Ve devamı } \\ \text { Y } & : \text { Yıl }\end{array}$

